ENTREPRENEURSHIP AND SUSTAINABILITY ISSUES

ISSN 2345-0282 (online) http://jssidoi.org/jesi/

2021 Volume 8 Number 4 (June)

http://doi.org/10.9770/jesi.2021.8.4(26)
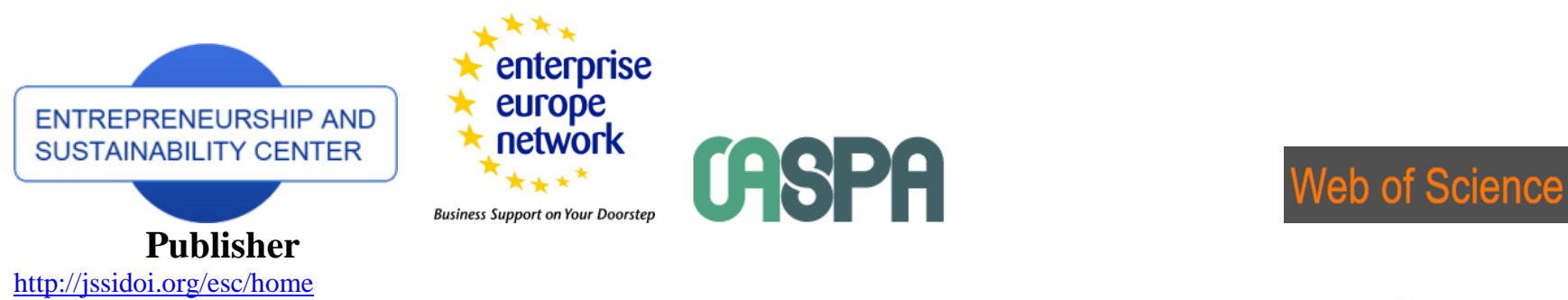

http://jssidoi.org/esc/home

Business Support on Your Doorstep

1 Clarivate

Analytics

\title{
THE TRANSITION TOWARDS TO THE CIRCULAR ECONOMY: EUROPEAN SMES' TRAJECTORIES
}

\author{
Alfonso Marino ${ }^{1}$, Paolo Pariso ${ }^{2}$ \\ 1,2 Università della Campania Luigi Vanvitelli, Viale Abramo Lincoln, 5, 81100 Caserta CE, Italy \\ E-mails:l'alfonso.marino@unicampania.it; ${ }^{2}$ paolo.pariso@unicampania.it
}

Received 15 January 2021; accepted 15 April 2021; published 30 June 2021

\begin{abstract}
The transition towards to the circular economy of European SMEs' is one of the items on the agenda in Europe. The aim of the paper is evaluate if this drive should transform our SMEs and keep European production sustainable and competitive. The paper presented a comparison analysis on the circular economy SMEs transition in the 13 sectors EU Member States. The study highlights and evaluates the transition in 13 sectors with highest SMEs performance. Five trajectories have been identified and evaluated in order to investigate, the transition degree of each sector towards to the circular economy. The analysis shows a heterogeneous transition with both sectors and Countries in which the presence of best practices, have been realized, but, can not be transfer to other sectors. A series of barriers to the transition from linear to circular economy are composed in the SMEs sectors.
\end{abstract}

Keywords: linear economy; circular economy; Europe, materials; SMEs

Reference to this paper should be made as follows: Marino, A., Pariso, P. 2021. The transition towards to the circular economy: European SMEs' trajectories. Entrepreneurship and Sustainability Issues, 8(4), 431-445. http://doi.org/10.9770/jesi.2021.8.4(26)

JEL Classifications: L2, L26

\section{Introduction}

The process of economic development and industrialization of our society, born with the industrial revolution, supported by the linear economy model. This pattern is linked to the idea of "take make dispose" by using raw materials as input and landfilling the products at the end of their life cycle (Murray et al., 2017). This model has reached points of no return, creating an imbalance between resource supply and goods demand. This imbalance extends to intangible but fundamental resources: air, water and soil. In this case, there is an imbalance between nature's regeneration rate and resource consumption rate. These are two strategic problems of the linear model (Michelini et. al., 2017). It is interesting to note that, both problems come together in the difficulty of achieving a possible sustainable development and preserve the planet for future generations (Stahel 2016). An alternative model of growth emerged in terms of the debate at, both theoretical and operative level. The big company, SMEs, Public Administration, Governments, make decisions, implement actions, classified as circular economy 


\section{ENTREPRENEURSHIP AND SUSTAINABILITY ISSUES}

ISSN 2345-0282 (online) http://jssidoi.org/jesi/

2021 Volume 8 Number 4 (June)

http://doi.org/10.9770/jesi.2021.8.4(26)

outcomes. Circular Economy (CE), described an economy system aimed at eliminating waste, pollution and reducing use of resources. A strategic trajectory of this model is reported to reuse, to sharing, to repair, refurbishment, remanufacturing and recycling, in order to create a close-loop system. This close - loop system aims at minimizing the use of raw material and the creation of output with waste, pollution and carbon emissions. All imbalance factors should become new raw material and, in this logic, the circularity means a regenerative action in term of both production and nature. The circularity support also, the creation of new jobs and market opportunity. It is interesting to note that, the European Commission (EC) has adopted a Circular Economy Action Plan in which the Member States supporting in the transition towards the CE. The transition is linked both, material and immaterial flows (Kirchherr et al., 2017). Following this research stream, Hislop and Hill (2011) considered the $\mathrm{CE}$ as a development strategy for a sustainable pattern aimed at supported the resource efficiency in terms both, material and immaterial flows. Preston (2012) focused on the regenerative actions able to support the transition towards the CE. The authors started from different points of view, they converge on the idea that the $\mathrm{CE}$ is a 3R system that influences the environment, the economy and the society. At theoretical level, Kirchherr et al. (2017) focused on the analysis by comparing 114 definitions of CE. Ghisellini et al. (2016) elaborated an ample systematic literature review (SLR) on CE issues. This SLR, evaluates circular economy, at micro, meso and macro level. Korhonen et al. (2018) focused on the emergent literature related to several fields identifying different variables, perspectives and contributions. However, only a few authors focused on the operative application at macro level (Ghisellini et al., 2016) for an extended geographical area (i.e. Europe). Following this research stream, this study focuses on the obstacles towards from linear to circular economy (Hopkinson et al., 2018) and proposes a framework to identify obstacles linked to change business model (Lloret, 2016) in European SMEs (EC, 2014). The study intends to contribute to an accumulation knowledge in a strategic change of the Europe in 13 sectors where SMEs are a strategic pillar of the European economy sustainability (Geissdoerfer et al., 2017). SMEs and its environmental impact (Dey et al., 2019; Dey et al, 2020) is a pivotal theme that is being increasingly implemented in the economic development of all sectors, both industrial and services. (Katz-Gerro et al., 2019; Rizos et al., 2015). At theoretical level, (Farooque et al, 2019; Parida et al, 2019; Saavedra et al., 2018; Møller et al., 2014) circular loop related to SMEs, is the result of regenerative strategy linked to raw material use, production structure and by different use of the physical, chemical and biological characteristics of the environment. At operative level, in Europe, interesting actions, (European Commission, 2015a; 2015b; 2018; 2019a; 2019b; 2019c; 2020) have been implemented to support the transition towards the circular economy SMEs. In this context, the European Environment Agency (EEA, 2020); highlights the need to address environmental challenges of unprecedented scale and urgency. Resources are not as unlimited as Meadows et al., 1972 explained. The convergence of these both, different theoretical and operational focuses converges on: the consumption of raw materials and energy (Tvaronavičienè et al, 2018, waste production (Rosa et al 2019). These considerations are important because: the use of non-renewable raw materials and available energy sources leads to the impoverishment of the planet to the detriment of future generations; waste degrades the environment. These issues highlight challenges and opportunities and is necessary to manage the activities of the enterprise appropriately (Genovese et al., 2017) from linear to circular economy (Türkeli et al., 2018) in order to make: a sustainable consumption (Lim, 2017) of raw materials and energy, to reduce the production of waste, to mitigate the environmental risk. What is the contribution of SMEs in Europe to boost this transition? European SMEs, produce $20 \%$ of total EU value added, 35 million jobs, Industry accounts for $80 \%$ of exports, $99 \%$ of European firms are small and medium sized businesses (EU 2020). European SMEs needs to become more circular while remaining competitive on the global stage. The Small Business Act is one of the key tools to understand the implementation of the circular economy in the SMEs sectors (Liu et al., 2018; Lieder et al., 2020). Starting from these assumptions and following the contributions of the literature in the following paragraph, our research question (RQ) is as follows: can this drive should transform our SMEs and keep European production sustainable and competitive? The paper is organized as follow: sections two outlines a conceptual background on the circular economy will be developed. Section 3 shows the methodology. Section 4 explains the results. Section 5 displays the discussion and related research limits. Finally, Section 6 shows the conclusions of the paper.

\section{Theoretical background}




\section{ENTREPRENEURSHIP AND SUSTAINABILITY ISSUES}

ISSN 2345-0282 (online) http://jssidoi.org/jesi/

2021 Volume 8 Number 4 (June)

http://doi.org/10.9770/jesi.2021.8.4(26)

The literature and the EU directive and recommendations indicate that most of the issues concerning the CE transition evolve around SMEs, its production, its raw material reuse and its disposal. In fact, SMEs management is considered by European Commission (2015a; 2015b; 2018; 2019a; 2019b; 2019c; 2020) in overall 28EU Member States a strategic enterprise to address the transition from linear to circular economy. Liu et al. (2017) focused on the SMEs sustainable performance under the concepts of the circular economy through "Reduce, Reuse and Recycle" (3R) rules. At theoretical and operative level, is underlined the need of an adequate support framework at investment and technologies level for the sustainable outcomes. Iacovidou et al. (2017b) highlight how sustainable results can create complex values useful in the transition towards to the circular economy. In addition, in line with the Small Business Act, the SMEs sustainability and its manage (Malinauskaite et al., 2017) is a strategic outcome in all 28 EU Member States. Minelgaite and Liobikienè (2019) focused on the importance of $3 \mathrm{R}$ behaviors as effective action to the support, in the European Union, of the SMEs transition from the linear to the circular economy. In this context, should be also pay more attention to the promotion of efficient consumption and production patterns. In fact, many studies focused on the relationship between the SMEs production and socioeconomic factors (Lu et al., 2017), and consumption (Bosire et al., 2017; Han et al., 2018; Huang et al., 2020) focused on SMEs, identifying socioeconomic and consumption as dominant drivers. In fact, Elia et al. (2017), highlighted the inadequacy of single factor, to support the transition. According to Elia et al. (2017), Iacovidou et al. (2017b), pointed out that the transition is both a complex and composite phenomena. The $\mathrm{CE}$ is a strategic objective and therefore a single factor does not explain the transition process (Marino, et al., 2020; Mazzoni, 2020). This analysis may be strategic to comprehend how the SMEs are implementing and should implement actions to boost the transition towards the CE. This problem is addressed by EU recommendations that suggest an intensification of actions such as Roadmap, Green deal and Circular procurement implementation. It is interesting to note that the main bottleneck concerns the achievement of the national transition objectives. From the analysis of the official reports emerges great differences in the transition results achieved within 28 Member States both in terms of the economic sector, private or public, that has driven the change and in terms of extent and degree of transition in each State. Criticalities that hinder the transition have emerged in terms of national government choices and connected to specific sectors and services. The efforts made by the Member States to shift their social and economic activities towards "circularity" have fostered changes in the business model and labor market, with new business models (Pieroni et al., 2019) and new opportunities resulting from the implementation of the 3Rs actions. This idea of SMEs circular economy considers it as a transformative economy redefining production and consumption patterns, inspired by ecosystems principles and restorative by design, which increases resilience, eliminates waste, pollution and creates shared value through an enhanced circulation of material and immaterial flows. It focuses on the key drivers of the paradigm: resource efficiency, sustainable economic growth, environmental protection and social development. The main idea is that the circular economy is a 3R system (Milios, et al., 2019) with predominantly environmental, economic and social impacts. Following this research stream Kristensen et al., (2020) analyzed the emerging literature from several domains to identify concepts and take into account the complexity of the issues and perspectives of the various contributions. Furthermore, European Commission considers the topic in overall production sector as a strategic issue to address the transition from linear to circular economy (Liu et al. 2018; Benachio et al 2020; Lahane et al., 2020; Iacovidou et al. 2017b). Winkler, (2011) reinforces these concepts with three structural barriers to enhancing product reuse circularity. The first is that a large part of the used materials is accumulated as in use, and the second is that a large amount of unrecycled materials is sent to landfill. Reusing used materials as raw materials (second raw material) is another strategic cornerstone. As the rates for some materials are already high, substantial improvements still appear possible. (Iacovidou et al., 2017a; Horodytska et al., 2018; Hahladakis et al., 2019; Gelhard et al., 2016). Following this research stream, preferring 3R materials to the raw materials, it is possible to influence the performance of SMEs both in relation with their production -transformation processes, by making them less energy- intensive, more resource efficient, and market competitiveness. It is interesting to note that the 3Rs strategy is a manufacturing strategy which is also driven by market conditions (Brissaud et al., 2017). the increase SMEs in secondary raw material use will open new markets, with positive actions concerning: reduce 


\section{ENTREPRENEURSHIP AND SUSTAINABILITY ISSUES}

ISSN 2345-0282 (online) http://jssidoi.org/jesi/

2021 Volume 8 Number 4 (June)

http://doi.org/10.9770/jesi.2021.8.4(26)

costs of production; increase businesses competitiveness; encourage new product development; create jobs; promote innovation (Dey et al., 2019); stimulate economic growth (EEA, 2013; 2018; 2020; EU, 2020; EASAC, 2016; Geng et al., 2012). The positive actions mentioned above provide interesting qualitative trajectories useful to interpret the degree of transition, in the different production sectors where SMEs are present, from linear to circular economy (Awasthi et al., 2018). From our research perspective, it is essential to outline the European context and analyze the trajectory of each sector in which SMEs have a strategic role. However, only a handful of authors were interested in operational application at the macro level (Ghisellini et al., 2016) for a geographical area in specific sectors (i.e. Europe), following a qualitative approach. This paper is designed to help fill this gap. The next paragraph will explain the modalities. The accumulation knowledge and application of strategic trajectories, should allow for the design of a circular economy achievement process. This analysis will be of interest to SMEs, researchers, policy makers and governmental planners, who can acquire information for the development of circular economy strategies in long-term plans.

\section{Research objective and methodology}

In order to investigate circular economy in 13 European sectors, $(2016-2020)$ it is necessary to understand how the sectors are implementing and should implement actions, starting from linear economy, to boost the transition towards the circular economy. It should be noted that, even if there are a large number of Official reports on the EU platforms (Eurostat, 2017a; 2017b; 2018; 2019; OECD, 2016; 2017; UN 2019), the ones chosen represent for the quality of the information, a useful tool for the survey carried out. Official reports, 24, were issued. Their common denominator was to accelerate the SMEs transition of European sectors towards from linear to circular economy. We elaborated this information and devised a synoptic framework to outline the progress made so far and to identify possibilities and opportunities for improvement. The 24 official reports are related to the : external survey and reports but also contributions received from chambers of commerce and business organizations related to. Analysing the official reports has been possible to accumulate knowledge in 13 European sectors in which SMEs, are strategic pillar. The accumulation knowledge is qualitative also if based on a large document analysis and take into account the trajectories towards from linear to circular economy. This accumulation knowledge starting from three different typologies of official reports: External surveys and reports; dedicated reports, surveys and contributions from chambers of commerce and other business organizations related; internal and external databases and reports.

The first typology is related to: Eurochambres, 'Business survey - EU Internal Market: Barriers and Solutions', 2019 (Eurochambres 2019 survey); World Bank Group, 'Doing Business 2019', 2019 (World Bank Doing Business report), Centre for European Policy Studies (CEPS), 'Hidden Treasures: Mapping Europe's sources of competitive advantage in doing business', 2019 (Hidden Treasures report); The Association of German Chambers of Commerce and Industry (DIHK), 'DIHK Survey on Single Market Obstacles 2019: Services, Goods and Investments' (DIHK 2019 survey); Dutch Ministry of Economy, Dutch export agency, 'Doing Business in Europe', 2018 (Dutch Doing Business in Europe survey);Estonian Ministry of Foreign Affairs and Communications, 'Mapping: applicable regulatory requirements for a construction company on its export journey to Estonia, Finland, and Sweden', 2018; Governments of Ireland, Denmark, Finland and Czechia, and Copenhagen Economics, 'Making EU Trade in Services Work for All: Enhancing innovation and competitiveness throughout the EU economy', November 2018. The second typology is linked to: Austrian Chamber of Commerce; Croatian Chamber of Economy; Cyprus Chamber of Commerce and Industry, Czech Chamber of Commerce; Confederation of Danish Industry; Confederation of Finnish Industries; French Chamber of Commerce and Industry; Latvian Chamber of Commerce and Industry; Malta Chamber of Commerce; Spanish Chamber of Commerce; Confederation of Swedish Enterprise. The third typology is related to: European Commission, Annual report on European SMEs 2017/2018', 2018 SOLVIT database, European Commission, 
ENTREPRENEURSHIP AND SUSTAINABILITY ISSUES

ISSN 2345-0282 (online) http://jssidoi.org/jesi/

2021 Volume 8 Number 4 (June)

http://doi.org/10.9770/jesi.2021.8.4(26)

European Central Bank, 'Investment Barriers 2019', European Enterprise Network, Intellectual Property SME Scoreboard 2019 Safety Gate.

In order to evaluate these Official reports, has been implemented the following qualitative method (Neuman 2014) each project has been evaluated starting from following qualitative variables: transparency, maximizes validity, maximizes reliability, comparative, reflexive. In table 1 in order to share the method have been reported the criteria and method to assess 24 SMEs official reports.

Table 1: Criteria and method to assess 24 SMEs official reports

\begin{tabular}{cc}
\hline Criteria & Method \\
\hline Transparent & $\begin{array}{c}\text { Provide a clear account of procedure used, an 'audit trail' that } \\
\text { others can follow (i.e. could the evidence - fieldwork notes, } \\
\text { interview transcripts etc - be inspected independently? Were } \\
\text { procedures for data analysis clearly described and justified?) }\end{array}$ \\
\hline $\begin{array}{c}\text { Maximizes } \\
\text { validity }\end{array}$ & $\begin{array}{c}\text { Analysis of cases that do fit within the RQ. Including enough } \\
\text { context for reader to judge interpretation }\end{array}$ \\
\hline $\begin{array}{c}\text { Maximizes } \\
\text { reliability }\end{array}$ & $\begin{array}{c}\text { Analyses of whole set of information. Using more than one } \\
\text { analyst/ coder }\end{array}$ \\
\hline $\begin{array}{c}\text { Comparative } \\
\text { Reflexive }\end{array}$ & $\begin{array}{c}\text { Accounts for the role of the SMEs in analyzed context i.e. take } \\
\text { into consideration the impact that its being part of an } \\
\text { institutional organization (in Italy i. e. may be the SMEs }\end{array}$ \\
\hline $\begin{array}{c}\text { institutional organization) might have had on the responses } \\
\text { given. Do you think Official reports might have exaggerated } \\
\text { certain problems for example? The researchers dos not be } \\
\text { swayed by favorite findings }\end{array}$ \\
\hline
\end{tabular}

In the next section, are identify the most important SMEs' obstacles per 13 sectors towards from linear to circular model.

\section{Results}

In order to answer the RQ official reports have been analysed, and 13 sectors assessed. The sectors are the ones where the concentration of SMEs in Europe is the highest.

- $\quad$ Architecture and engineering

- $\quad$ Automotive

- Chemicals

- Construction

- $\quad$ Electronic communications networks and services

- $\quad$ Energy

- $\quad$ Food and beverages

- Hotels and accommodation

- Industrial machinery

- Pharma

- Fashion

- $\quad$ Public transport

- Waste management

The concentration ratio is between the minimum value of $53 \%$, in the food and beverage sector, to $96 \%$ of chemicals (Annual Report on European SMEs 2018/2019). The analysis of 13 sectors underlines different results in terms of the change from the linear to the circular economy. 


\section{ENTREPRENEURSHIP AND SUSTAINABILITY ISSUES}

ISSN 2345-0282 (online) http://jssidoi.org/jesi/

2021 Volume 8 Number 4 (June)

http://doi.org/10.9770/jesi.2021.8.4(26)

\subsection{Architecture and engineering}

This sector shows, $67 \%$ of SMEs. It is a knowledge-intensive sector and can play a supporting role in the transformation from linear to circular. Architecture and engineering companies face obstacles at different stages of their service production to move from a linear to a circular economy. The circular economy, based, as seen in the conceptual background, on the principle of $3 \mathrm{R}$, highlights the need for the reuse of materials, for a capacity to extract from the waste of the second raw material. This regeneration, needs to in the design phase knows the performance of the product. The use of these materials, in this phase of transition, from the linear to the circular model, highlights the need for services for companies oriented towards the dissemination and development of this knowledge. It is interesting to note, that the analysed report, highlight the practice, for the short time, of the principle of free movement of professionals applies and in most cases only allows for a prior declaration requirement by the host Member State. This principle has brought an interesting cross contamination in terms of exchange of knowledge within the sector. This exchange of knowledge is possible between EU Member States, infact, access is regulated and professional performance is possible. Examining the twenty four official reports, the challenges are linked to dissemination knowledge based on management and protection of resources. As we will see this criticality is present, although with similar characteristics, also in other sectors analysed. The obstacles, are linked to the technical and knowledge barriers. Particularly, in terms of technical barriers the most important bottleneck are linked to lack of expertise in production and use, while, in terms of knowledge the bottleneck are linked to weakness of R\&D.

\subsection{Automotive}

This sector shows, 57\% of SMEs. It is a technological-intensive sector and can play a supporting role in the transformation from linear to circular. Two main trajectories can be highlighted in this area. The first relates to the old car market, linked to the mechanical engine and connected to petrol, this car, which is highly polluting, is still in circulation in the individual Member States and the policies of the individual States, have a strong mismatch that does not in fact speed up the switch from a linear to a circular economy. The second trajectory relates to the new vehicle sector, which is currently subject to harmonised standards in the EU in the context of the EU typeapproval framework (Directive 2007/46/EC and soon Regulation (EU) No.2018/858 on emissions and safety). These standards mean that all new vehicles sold in the EU are in principle subject to the same technical requirements for emissions and safety. This is a good step towards the transition to the new circular business model in all Member States. In the official report analysed, some barriers have emerged that have been pointed out by SMEs that could prevent the transition from the linear to the circular model. The first concerns financial resources availability, which is directly linked to the second, the difficulties of producing products that support climate change. These critical issues are particularly important in the case of integrated mobility services, which on the one hand can incentivize a different model of cars, for example not related to single transport and on the other, rely on different types of vehicles to be integrated into a complex system. The obstacles, are linked to the commercial and regulatory barriers. Particularly, in terms of commercial barriers the most important bottleneck are linked to the difficult to source second raw materials, while, in terms of regulatory, the bottleneck are linked to SMEs difficult to get clearance for new raw material production.

\subsection{Chemicals}

This sector shows the highest percentage of SMEs. EU chemical legislation deals with the complexity of chemical risks and has been instrumental in ensuring free circulation of substances, mixture and articles within the EU market. Analysing the official reports, emerging some bottlenecks related to a more circular production and use of chemicals in Europe. The reuse of raw material is a strategic tool related to boost the transition from linear to circular model in this sector. The resources assigned to this transition are still weak. It is also important underline that from national Government and at EU level, there is a lack of access to finance and other incentives related to the transition. In Europe, there are SMEs producing and using safer alternatives, e.g. use of less hazardous chemicals, but have not received appropriate funding to sustain this strategic approach. Analysing the official reports, emerging some bottlenecks related to financial resources availability but also, to save in the supply of 


\section{ENTREPRENEURSHIP AND SUSTAINABILITY ISSUES}

ISSN 2345-0282 (online) http://jssidoi.org/jesi/

2021 Volume 8 Number 4 (June)

http://doi.org/10.9770/jesi.2021.8.4(26)

power. The obstacles are related to reuse material, in terms of raw material association with production cycle and misconception that linear products are better built.

\subsection{Construction}

This sector shows, $67 \%$ of SMEs. The sector, in order to accelerate the SMEs transition lead to one hand both regenerate and reuse materials and, the other, knowdledge actions for service providers active in the market. The transition process (Benachio et al 2020), take into account not only the traditional SMEs mission, to build, but also the innovative actions linked to technological opportunities. To build must be combined with environmental sustainability (Dey et al., 2020) and therefore, buildings were made more efficiently from the energy saving viewpoint. The integration, coordination and control, of digital technologies in construction has to be carefully implemented in terms of service delivery, e.g., to develop technologies for building data collection and processing. The sector, in terms of analysis linked to official reports, highlight the importance of, savings in the supply of power and mitigation climatic change. The obstacles, in terms of barriers that delay the transition from linear to circular economy, technical and regulatory actions are strategic to make up for the accumulated delay.

\subsection{Electronic communications networks and services}

The existence of high-speed consume of electronic both goods and services, if one hand determinate a development of the digital market, on the other, produce electronic wastes with a low level of reuse or regenerative actions. In this sector, but also in Construction, the lack of reuse and regeneration of materials represent sunken costs related to pollution and waste of raw materials as not only in the sector, but assess the high-speed consume, this sunk costs are related to all business model. Particularly, come back to the sector, from analysis of official reports is possible to note an attention related to wellness and economic growth. This challenge is linked to the necessity of increase the level of reuse and regeneration of materials to accelerate the transition. The obstacles related to the transition from the linear to the circular economy of SME in this sector, the main barriers are linked to 3R materials: raw material association with production cycle and misconception that linear products are better built.

\subsection{Energy}

This sector shows, 77\% of SMEs. Energy is one of strategic economic good, energy is: an input to the production of almost every other good and service and a good output, in the modern economy. In the sector, analyzing the official reports, there are challenges linked to the transition in terms of savings in the supply of power, mitigation climatic change, wellness and economic growth. These challenges may be overcome starting from a different action of EU, in particular changing the limited role of EU legislation based on complex procedures that can create technological and organizational (Gelhard et al., 2016) changes by SMEs in terms of acceleration of the transition. In order to assess the obstacle to the transition, the main barrier is linked to a regulatory and in specific way, legislation lack by EU and government.

\subsection{Food and beverages}

This sector shows, $58 \%$ of SMEs. Analyzing official reports related to SMEs in food and beverage, the transition could have a positive impact in different stage of production and delivery. The main challenges are related to waste prevention, resource efficiency water and energy included (see introduction) or extension of life-cycle products, in production stage and labelling in service delivery. Furthermore, some factors such as partnerships, applied research or innovation (Dey et al., 2019) could act as key-factors at any step of the cycle. In order to support these actions, savings in the supply of power and wellness and economic growth are the strategic actions related to all SMEs ane stakeholder (ECSPR; 2018; 2019) of sector. The obstacles, are linked to SMEs' lack of knowledge and big companies' profitability as main barriers, knowledge and commercial, to the transition from the linear to the circular economy of SMEs. 


\section{ENTREPRENEURSHIP AND SUSTAINABILITY ISSUES}

ISSN 2345-0282 (online) http://jssidoi.org/jesi/

2021 Volume 8 Number 4 (June)

http://doi.org/10.9770/jesi.2021.8.4(26)

\subsection{Hotels and accommodation}

This sector shows, $68 \%$ of SMEs. The transition in this sector could begin when the customer books a travel and accommodation, so it starts when the customer decides the preferred destination. It is possible to individuate six steps: travels; reaching his destination; uses local transports; accommodation; consumes food; finally, he travels back. All six steps are compatible with circular economy. In this sector, the active role of the consumer, his knowledge, are essential to boost the transition. The challenges are linked to savings in the supply of power, mitigation climatic change, wellness and economic growth. The obstacles in terms of main barriers are related to consumers' knowledge (knowledge), transport costs (commercial), quality certification (regulatory).

\subsection{Industrial machinery}

This sector shows, 57\% of SMEs. In this sector, some challenges are emerging to the SMEs. The challenges are related to low ratio of reused materials to their circularity, but the strategic action, in order to boost circular loop consist in the missing product and services standards in new technologies e. g., artificial intelligence and internet of things. The delay in managing this criticality could increase the costs and information asymmetry of SMEs. This problem, which emerged from the study of the twenty-four official reports, is linked to the challenges of the financial resources availability and dissemination knowledge based on management and protection of resources. The obstacles, in terms of main barriers are related to storage, big companies' profitability and weakness of SMEs in start up (commercial). These barriers, related to the implementation of circular loop are linked also to initial capital processing plants (technical) and SMEs' lack of knowledge (knowledge) and legislation lack by EU and government (regulatory).

\subsection{Pharma}

This sector shows, $75 \%$ of SMEs. The sector has published a White Paper on the 'circular economy', focusing on its importance to the sector and the measures needed to move towards greater sustainability. This approach provides investments in green pharm. In the sector, the shift to a circular economy of SMEs is, also related to industrial secrecy. It is interesting to note that the circular loop could help drive the industry's innovative skills, driving the efficient use of materials and improving the business value of SMEs in the long term. Analyzing the official reports, the most important challenges are related to savings in the supply of power, dissemination knowledge based on management and protection of resources, wellness and economic growth. The obstacles, in terms of main barriers, are linked to regulatory: legislation lack by EU and governments, SMEs difficult to get clearance for new raw material production and 3R materials: associated with raw material association with production cycle.

\subsection{Fashion}

This sector shows, $67 \%$ of SMEs. The sector, the big companies, has implemented fast fashion, i.e. processing cycles of less than 21 days the collections are designed, manufactured and distributed (Jia et al., 2020). It is a model of programmed obsolescence that speeds up the use of circulating material but, not its reuse or regeneration. Also in this sector, fast strategy actions show little attention to sustainability and pollution in its different forms. This cycle is typical of a linear economy that does not plan to close the circuit. SMEs in the sector are implementing elements of circular economy. Starting from the design trying to contain waste as emerges from the analysis of official reports, the most important challenges are linked to: savings in the supply of power and mitigation climatic change. In order to address these challenges the principal actions are linked to: facilitate the repair of parts in order to recycle them or give them a second life; use quality materials with a timeless design to maximize their usability, make products with biodegradable or at least recyclable materials. The obstacles related to main barriers are related to technical, commercial and knowledge barriers: lack of expertise in production and use, initial capital processing plants, difficult to source second raw materials, storage, big companies' profitability and weakness of SMEs start up. 


\section{ENTREPRENEURSHIP AND SUSTAINABILITY ISSUES}

ISSN 2345-0282 (online) http://jssidoi.org/jesi/

2021 Volume 8 Number 4 (June)

http://doi.org/10.9770/jesi.2021.8.4(26)

\subsection{Public transport}

This sector shows, $63 \%$ of SMEs. The public transport sector, in order to improve its circular loop, should achieve a twofold objective: the shift from fuel consumption - fossil fuels - to clean energy power for bus traffic and, to improve the supply sector in relation to the choice of materials by replacing the current ones, with those with a high percentage of reuse and recycling. The challenges related to these improvements are savings in the supply of power, mitigation climatic change, dissemination knowledge based on management and protection of resources, wellness and economic growth. The obstacles in terms of main barriers to the transition from the linear to the circular economy of SMEs, are linked to 3R materials, raw material association with production cycle and, technical, lack of expertise in production and use and, knowledge, SMEs' lack of knowledge, weakness of R\&D.

\subsection{Waste management}

This sector shows, $62 \%$ of SMEs. In addition, this sector, waste management, as all previous sectors, is part of the transition towards a circular economy. The Action Plan for a Circular Economy sets up a concrete action plan that covers the whole life cycle of a product: from production and consumption to waste management and the secondary materials market. The principal challenges are linked to saving in the supply of power, mitigation climatic change, dissemination knowledge based on management and protection of resources, wellness and economic growth. The obstacles in terms of main barriers to the SMEs transition from the linear to the circular economy are related to technical (lack of expertise in production and commercial (difficult to source second raw materials and storage), knowledge (SMEs' lack of knowledge and weakness of R\&D), regulatory (quality of certification) 3R materials (raw material association with production cycle). The synthesis of challenges, primary role of the SMEs in the sector and circular economy objectives are displays in table 2.

Table 2. Challenge Primary role of the SMEs and circular economy objectives

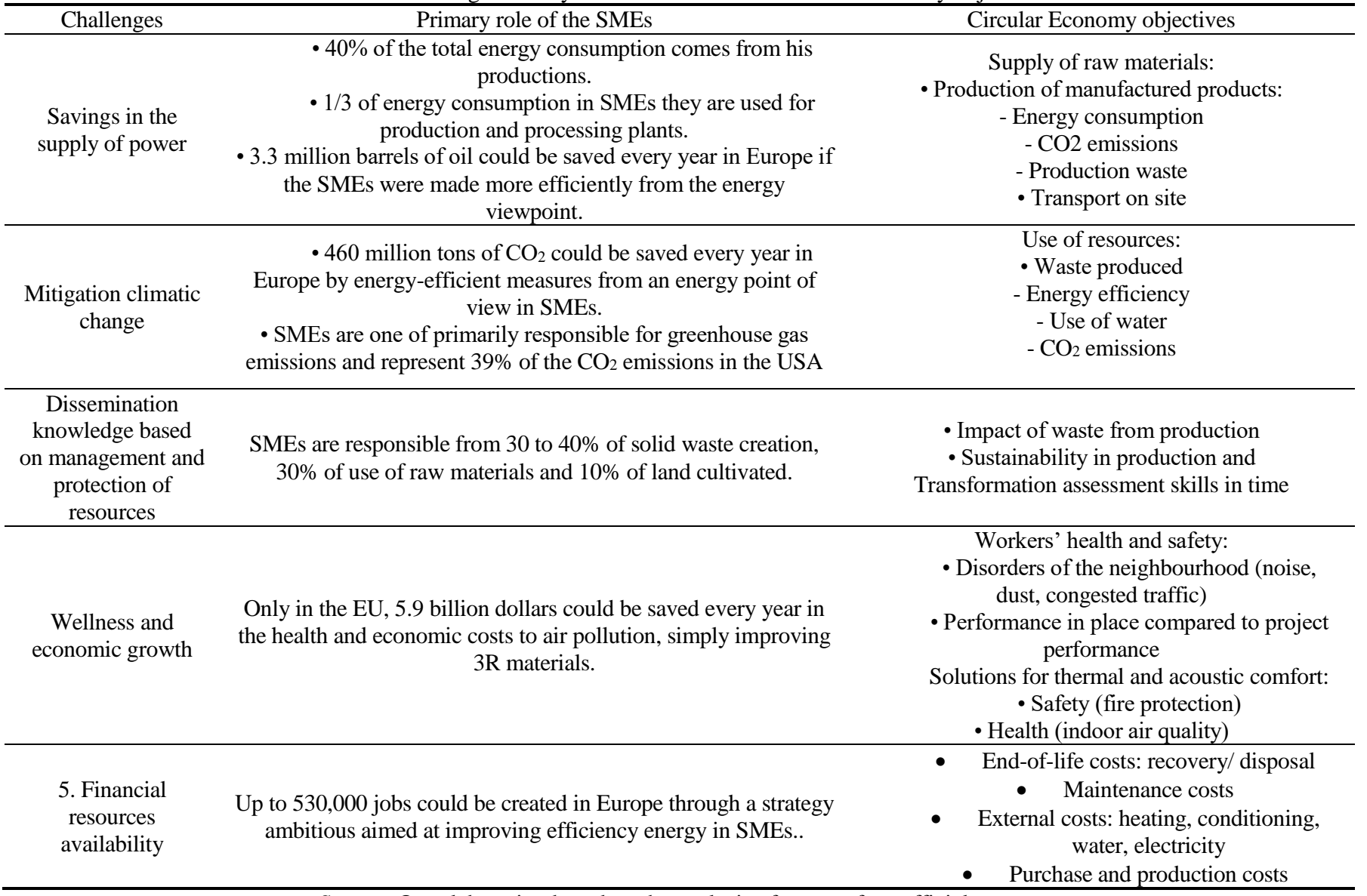

Source: Our elaboration based on the analysis of twenty-four official reports 
ENTREPRENEURSHIP AND SUSTAINABILITY ISSUES

ISSN 2345-0282 (online) http://jssidoi.org/jesi/

2021 Volume 8 Number 4 (June)

http://doi.org/10.9770/jesi.2021.8.4(26)

Table, sums up the results from 4.1 to 4.13 . In Table 2, after the challenges have been identified, the primary roles of SMEs in relation to their current linear economy-based production cycle have been identified by the analysis of the 24 documents. In the next column, again from the analysis of the official reports, the main objectives of the transitions that must see SMEs protagonists have been identified. The main barriers to the transition have been identified in table 3.

Table 3 Main barriers to the transition from the linear to the circular economy of SMEs

\begin{tabular}{|c|c|c|c|c|}
\hline Technical & Commercial & Knowledge & Regulatory & 3R materials \\
\hline $\begin{array}{l}\text { Lack of expertise in } \\
\text { production and use } \\
\text { Initial capital } \\
\text { Processing plants }\end{array}$ & $\begin{array}{l}\text { Difficult to source } \\
\text { second raw materials } \\
\text { Storage } \\
\text { Transport costs } \\
\text { Big companies' } \\
\text { profitability } \\
\text { Weakness of SMEs in } \\
\text { start up }\end{array}$ & $\begin{array}{l}\text { SMEs' lack of } \\
\text { knowledge } \\
\text { Weakness of } \\
\text { R\&D } \\
\text { Consumers' } \\
\text { knowledge }\end{array}$ & $\begin{array}{l}\text { Legislation lack by EU and } \\
\text { government } \\
\text { SMEs difficult to get clearance } \\
\text { for new raw material production } \\
\text { Quality certification. }\end{array}$ & $\begin{array}{l}\text { Raw material association } \\
\text { with production cycle } \\
\text { Misconception that linear } \\
\text { products are better built. }\end{array}$ \\
\hline
\end{tabular}

The principal barriers are five: technical, commercial; knowledge; regulatory; 3R materials and have been declined into specific points.

\subsection{Technical standpoint}

In the last decade, following the SMEs positive performance, have been developed second raw materials in many of sectors examined. In Construction sector hemp-concrete and various types of insulations for both internal and external wall sides, are interesting transition from linear to circular economy. These second raw materials, in all sectors analyzed, result from the combination of a design, production and transformation matrix. Within this matrix some materials plays a main role. Several studies focused on the properties of these materials, one among the most interesting is the ability to reduce $\mathrm{CO} 2$ during manufacturing, both in the transformation growing phase and in the production process, so that this materials can be considered as a base useful to develop a circular loop. It is interesting to note, despite these potentialities, that technical barriers are linked to the lack of expertise in both the production, design and transformation.

\subsection{Commercial standpoint}

Despite the production with linear economy modality, of the SMEs, the circular loop developing in all sectors. This trend, is the result of several factors, on one hand the increase of the demand for natural products, the growth of the people awareness about the environment sustainability, the rise of raw material and petrol costs; on the other hand, the improving of techniques, production practices and industrial equipment. In line with this assumption, SMEs production should be profitable from an economic standpoint, since it should be competitive not only with other materials, but with other production alternatives as well. Some of the barriers limiting circular loop and its development and causing potential profitability issues for the SMEs are the too long storage process before delivery and, the transportation costs, which could have a negative implication on economic and environmental feasibility.

\subsection{Knowledge standpoint}

Among the stakeholders, a general lack of knowledge on 3r materials exists. Usually, they ignore the potential advantages of this application. In particular, the sectors before highlighted, are not aware of the benefits of this circular loop. In fact, the difficulties to overcoming this barrier starts first of all within SMEs that could realize thanks to the increase in its use a new market, higher visibility and a knowledge slot linked to environmental and economic sustainability. 


\section{ENTREPRENEURSHIP AND SUSTAINABILITY ISSUES}

ISSN 2345-0282 (online) http://jssidoi.org/jesi/

2021 Volume 8 Number 4 (June)

http://doi.org/10.9770/jesi.2021.8.4(26)

\subsection{Regulatory standpoint}

Orienting adequate government actions to a favourable legislation means to recognize a positive identity to use second raw materials linked both to the production, with quality certification that ensure national quality standards, and to product, affecting in that way the ISO normative. In line with this, the growing in circular loop, thanks to its features of being materials with low pollution, could be a profitable alternative.

\subsection{R materials}

Despite there is not a great difference between raw material and second, the public opinion seems to be confused associating second to the idea that linear products are better built. In this case, the design competences are strongly required to improve these misconceptions. $3 \mathrm{R}$ materials associated with production cycle could be a first step to boost the transition from linear to circular model. In addition, environmentally friendly solution are generally associated only with reduced production costs in all sectors, belittling $3 \mathrm{R}$ materials that also offers others well-established benefits.

\section{Discussion and limits of research}

The results highlight that in terms of consumption for production, the reference to $40 \%$ of the total energy consumption comes from his productions. 1/3 of energy consumption in SMEs they are used for production and processing plants and 3.3 million barrels of oil could be saved every year in Europe if the SMEs were made more efficiently from the energy viewpoint contribute to the wealth produced. At the same time, 460 million tons of $\mathrm{CO} 2$ could be saved every year in Europe by energy-efficient measures from an energy point of view in SMEs. Furthermore, SMEs are one of primarily responsible for greenhouse gas emissions and represent $39 \%$ of the $\mathrm{CO} 2$ emissions and SMEs are responsible from 30 to $40 \%$ of solid waste creation, $30 \%$ of use of raw materials and $10 \%$ of land cultivated. At the same time, only in the EU, 5.9 billion dollars could be saved every year in the health and economic costs to air pollution, simply improving 3R materials. Furthermore, up to 530,000 jobs could be created in Europe through a strategy ambitious aimed at improving efficiency energy in SMEs useful improvements to be made for the transition from a linear to a circular economy. As evidenced by the analysis of literature in the conceptual background, SMEs are one of the fundamental pillars for the transition from linear to circular model. They emerge from the analysis of official reports, the results of the research, highlight, 5 barriers: technical, commercial; knowledge, regulatory, 3R materials, that must be quickly removed to accelerate the transition. These issues are partly present in the literature, for example those concerning the barriers knowledge and 3R material, (Benachio et al 2020) while the technical ones, linked to the lack of expertise in production and use, the initial capital processing plants are less well known and debated. At the same time, with regard to trade barriers, the points that have emerged: difficult to source second raw materials, storage, transport costs and big companies' profitability, are not much discussed in the literature, but represent variables that affect the modalities and timing of the transition. In addition, it is interesting to note that even in the presence of important legislative production by the EU, there is a regulatory gap between and within sectors among smes present in the different EU Member States (Marino et al, 2020). This legislative vacuum is evident in the request in the documents analyzed, by the stakeholders for a quality certification of products and productions coming from the use of the second raw material. The picture that emerges is that of a transition on the road, which in some sectors has interesting strengths, good practices achieved, which for the barriers described in the results, in particular those of regulation, can not be exported to other Member States of the Union. At this point of the paper the answer to the RQ is that the ambition of SMEs is to overcome the challenge of transition, but they emerge, beyond the wellknown and debated knowledge and 3R materials, but there are also three other trajectories, which, while complicating the transition, provide a clearer picture of the challenges facing European SMEs.

The limitations of this work are linked to the need for an analysis of the new barriers that have emerged, in particular technical, commercial and regulatory barriers. Such research can be developed in the future. 


\section{ENTREPRENEURSHIP AND SUSTAINABILITY ISSUES}

ISSN 2345-0282 (online) http://jssidoi.org/jesi/

2021 Volume 8 Number 4 (June)

http://doi.org/10.9770/jesi.2021.8.4(26)

\section{Conclusions}

The paper presented a comparison analysis on the circular economy SMEs transition in the 13 sectors EU Member States. Starting from SMEs environmental sustainability and conceptual background, the study describes the state of art of 13 sectors with highest SMEs performance. Moreover, five trajectories have been elaborated in order to investigate the transition degree of each sector towards the circular economy. The analysis shows a heterogeneous transition with sectors in which the presence of best practices, e.g., 3R materials, can not be transfer to other sectors. An interesting feature, by analyzing the sectors, is represented by the fact that some barriers to the transition from linear to circular economy are composed by sectors in which SMEs are leader. These performances are interesting also at operative level. In conclusion, it can be observed that in order to reduce the gap within the $13 \mathrm{EU}$ sectors it is necessary to develop ambitious government actions to support SMEs. This necessitates a strong economic structure, a willingness of the governments in term of policies, an entrepreneurial culture on the sector able to understand the circular loop opportunities behind this change. This transition is an opportunity to enhance economic context. The circular economy is an open question, and therefore at the end of this paper is possible to approve a stance whereby the transition must be seen as under constant development and reinterpretation.

\section{References}

Annual European SMEs (2019). Annual Report on European SMEs, Retrieved on December 5, 2020 from https://europeanstartupnetwork.eu/wp-content/uploads/2020/01/SME-Annual-report-2018-2019.pdf)

Awasthi, A.K., Cucchiella, F., D'Adamo, I., Li, J., Rosa, P., Terzi, S., Zeng, X., (2018). Modelling the correlations of e-waste quantity with economic increase. Science of the Total Environment, 613, 46-53. https://doi.org/10.1016/j.scitotenv.2017.08.288

Benachio, G. L. F., Freitas, M. D. C. D., \& Tavares, S. F. (2020). Circular economy in the construction industry: A systematic literature review. Journal of Cleaner Production, 121, 46. https://doi.org/10.1016/j.jclepro.2020.121046

Bosire, E. Oindo, B. and Atieno, J.V. (2017). Modeling Household Solid Waste Generation in Urban Estates Using Socioeconomic and Demographic Data, Kisumi City, Kenia. Retrieved on December 5, 2020 from https://repository.maseno.ac.ke/handle/123456789/441 Brissaud, D., Zwolinski, P., (2017). The scientific challenges or a sustainable consumption and production scenario: the circular reuse of materials for the upgrading and repurposing of components. Procedia CIRP 61, 663-666. CIRP Journal of Manufacturing Science and Technology 4 (3), 243-246. https://doi.org/10.1016/j.procir.2016.11.148

Dey, P. K., Malesios, C., De, D., Chowdhury, S., \& Abdelaziz, F. B. (2019). Could lean practices and process innovation enhance supply chain sustainability of small and medium-sized enterprises? Business Strategy and the Environment, 28(4), $582-598$.

https://doi.org/10.1002/bse.2266

DIHK (2019). The Association of German Chambers of Commerce and Industry Retrieved on December 5, 2020 from: Survey on Single Market Obstacles 2019: Services, Goods and Investments. https://www.dihk.de/resource/blob/14670/e054b36dc31b89c19813726586f8a3d3/dihk-binnenmarktumfrage-2019-engl-data.pdf Dutch Ministry of Economy (2018). Dutch export agency, 'Doing Business in Europe', Retrieved on December 5, 2020 from https://www.pwc.nl/nl/assets/documents/pwc-doing-business-in-the-netherlands-2018.pdf

EASAC, (2016). Indicators for a Circular Economy. European Academies' Science Advisory Council, Halle. Retrieved on December 5, 2020 from https://www.interacademies.org/sites/default/files/publication/easac-indicators_for_a_circular_economy.pdf

EEA (2020). Environment in Europe: State and Outlook in 2020, Synthesis Report, Retrieved on December 5, 2020 from

https://www.eea.europa.eu/soer

EEA, (2013). Municipal waste management in Italy Retrieved on December 5, 2020 from. https://www.e

ea.europa.eu/publications/managing-municipal-solid-waste/italy-municipal-wastemanagement

Elia, V., Gnoni, M. G., \& Tornese, F., (2017). Measuring circular economy strategies through index methods: A critical analysis. Journal of Cleaner Production 142, 2741-2751. https://doi.org/10.1016/j.jclepro.2016.10.196

Eurochambres, (2019). 'Business survey - EU Internal Market: Barriers and Solutions', Retrieved on December 5, 2020 from

https://www.eurochambres.eu/priority/single-market/

European Circular Economy Stakeholder Platform (2019). Retrieved on December 5, 2020 from

http://cdlink2.eesc.europa.eu/m/1/76282871/p1-b19044be4818fc7c414b6d89b98905a6051293/1/13/

European Circular Economy Stakeholder Platform, (2018). Retrieved on December 5, 2020 from

https://circulareconomy.europa.eu/platform/en/good-practices/luxembourgs-climate-pact-now-alsomainstreams-circular-economy-local-

policy. 


\section{ENTREPRENEURSHIP AND SUSTAINABILITY ISSUES}

ISSN 2345-0282 (online) http://jssidoi.org/jesi/

2021 Volume 8 Number 4 (June)

http://doi.org/10.9770/jesi.2021.8.4(26)

European Commission, (2015a). Closing the Loop: An Action Plan for the Circular Economy. Retrieved on December 5, 2020 from

https://ec.europa.eu/commission/priorities/jobs-growth-and-investment/towards-circular-economy_en.

European Commission, (2015b). Towards a circular economy. Retrieved on December 5, 2020 from

https://ec.europa.eu/commission/priorities/jobs-growth-and-investment/towards-circular-economy_en.

European Commission, (2018). Flash Euro barometer 456, SMEs, resource efficiency and green markets, Retrieved on December 5, 2020

from http://ec.europa.eu/commfrontoice/publicopinion/index.cfm/ResultDoc/download/DocumentKy/81280.

European Commission, (2019a). Circular Economy Retrieved on December 5, 2020 from

https://ec.europa.eu/growth/industry/sustainability/circular-economy_en.

European Commission, (2019b) Second Environment Implementation Review (EIR). Retrieved on December 5, 2020 from

https://ec.europa.eu/environment/eir/index_en.htm

European Commission, (2019c). European economic and social committee and the committee of the regions on the implementation of the circular economy action plan COM/2019/190 final. Retrieved on December 5, 2020 from

https://eur-lex.europa.eu/legal-content/EN/TXT/?qid=1551871195772\&uri=CELEX:52019DC0190

European Commission, (2020). Brussels Retrieved on April 5, 2020 from https://eur-lex.europa.eu/resource.html

European Council (2014). Conclusions, Energy and Climate framework 2030, Retrieved on December 20, 2020 from

https://ec.europa.eu/clima/policies/strategies/2030 en\#tab-0-0

European Environment Agency, EEA, (2018). Resource productivity, Retrieved on December 5, 2020 from

https://www.eea.europa.eu/airs/2018/resource-efficiency-and-low-carbon-economy/resource-efficiency

European Union (2020.) "A European industrial strategy, A new Industrial Strategy for a globally competitive, green and digital Europe"

$\begin{array}{llllll}\text { Retrieved on } & \text { December } & 5, & 2020 & \text { from }\end{array}$

nited.net/cms/upload/sectors/robotics/pdf/March2020_EU_industrial_strategy_en.pdf.pdf

Eurostat, (2017a). Circular economy indicators. Retrieved on December 5, 2020 from https://ec.europa.eu/eurostat/web/circular-

economy/indicators/monitoring-framework

Eurostat, (2017b). Waste generation by packaging material. Share of treatment of all pack-aging waste in 2016. Retrieved on December 5, 2020 from https://ec.europa.eu/eurostat/statistics-explained/pdfscache/10547.pdf

Eurostat, (2018). Retrieved on December 5, 2020 from https://ec.europa.eu/eurostat/documents/3859598/9407565/KS-FT-18

Eurostat, (2019). https://ec.europa.eu/eurostat/web/international-trade-in-goods/data/database.

EW-MFA Eurostat, (2010). Retrieved on December 5, 2020 from https://ec.europa.eu/eurostat/documents/1798247/6191533/2013-EWMFA-Guide-10Sep2013.pdf/54087dfb-1fb0-40f2-b1e4-64ed22ae3f4c

Farooque, M., Zhang, A., Thurer, M., Qu, T., \& Huisingh, D. (2019). Circular supply chain management: A definition and structured literature review. Journal of Cleaner Production. 228, 882-900. https://doi.org/10.1016/j.jclepro.2019.04.303

Geissdoerfer, M., Savaget, P., Bocken, N. M., \& Hultink, E. J. (2017). The circular economy-A new sustainability paradigm? Journal of Cleaner Production, 143, 757-768. https://doi.org/10.1016/j.jclepro.2016.12.048

Gelhard, C., \& von Delft, S. (2016). The role of organizational capabilities in achieving superior sustainability performance. Journal of Business Research, 69(10), 4632-4642. https://doi.org/10.1016/j.jbusres.2016.03.053

Geng, Y., Fu, J., Sarkis, J., Xue, B., (2012). Towards a national circular economy indicator sys- tem in China: an evaluation and critical analysis. Journal of Cleaner Production, 23 (1), 216-224. https://doi.org/10.1016/j.jclepro.2011.07.005

Ghisellini, P., Cialani, C., Ulgiati, S. (2016). A review on circular economy: the expected transition to a balanced interplay of environmental and economic systems. Journal of Cleaner Production, 114, 11-32. https://doi.org/10.1016/j.jclepro.2015.09.007

Genovese, A., Acquaye, A.A., Figueroa, A., \& Koh, S.C.L. (2017). Sustainable supply chain management and the transition towards a circular economy: Evidence and some applications. Omega, 66 (Part B), 344-357. https://doi.org/10.1016/j.omega.2015.05.015

Han Z., Liu Y., Zhong M., Shi G., Li Q., Zeng D., Zhang Y., Fei Y., and Xie Y. (2018) Influencing factors of domestic waste characteristics in rural areas of developing countries. Waste Management, 72, 45 - 54, https://doi.org/10.1016/j.wasman.2017.11.039 Hahladakis, J.N., Iacovidou, E., (2019). An overview of the challenges and trade-offs in closing the loop of post-consumer plastic waste (PCPW): focus on recycling. Journal of hazardous materials, 380, 120887. https://doi.org/10.1016/j.jhazmat.2019.120887

Hislop, H., Hill, J., (2011). Reinventing the Wheel: A Circular Economy for Resource Security. Green Alliance. London

Hopkinson, P., Zils, M., Hawkins, P., \& Roper, S. (2018). Managing a complex global circular economy business model: Opportunities and challenges. California Management Review, 60(3), 71-94. https://doi.org/10.1177/0008125618764692

Horodytska, O., Valdés, F.J., Fullana, A., (2018). Plastic flexible films waste management-a state of art review. Waste Management, 77, 413-425. https://doi.org/10.1016/j.wasman.2018.04.023

Huang, Q., Chen, G., Wang, Y., Xu, L., and Chen, W. Q., (2020) Identifying the socioeconomic drivers of solid waste recycling in China for the period 2005-2017. Science of The Total Environment, 725, 138137. https://doi.org/10.1016/j.scitotenv.2020.138137

Iacovidou, E., Millward-Hopkins, J., Busch, J., Purnell, P., Velis, C.A., Hahladakis, J.N., Brown, A., (2017a). A pathway to circular economy: developing a conceptual framework for complex value assessment of resources recovered from waste. Journal of Cleaner Production, 168, 1279-1288. https://doi.org/10.1016/j.jclepro.2017.09.002 


\section{ENTREPRENEURSHIP AND SUSTAINABILITY ISSUES}

ISSN 2345-0282 (online) http://jssidoi.org/jesi/

2021 Volume 8 Number 4 (June)

http://doi.org/10.9770/jesi.2021.8.4(26)

Iacovidou, E., Velis, C.A., Purnell, P., Zwirner, O., Brown, A., Hahladakis, J., Williams, P.T., (2017b). Metrics for optimising the multidimensional value of resources recovered from waste in a circular economy: A critical review. Journal of Cleaner Production, 166, 910938. https://doi.org/10.1016/j.jclepro.2017.07.100

Jia, F., Yin, S., Chen, L., \& Chen, X. (2020). Circular economy in textile and apparel industry: A systematic literature review. Journal of Cleaner Production, 120, 7-28. https://doi.org/10.1016/j.jclepro.2020.120728

Katz-Gerro, T., \& López Sintas, J. (2019). Mapping circular economy activities in the European Union: Patterns of implementation and their correlates in small and medium-sized enterprises. Business Strategy and the Environment, 28(4), 485-496.

https://doi.org/10.1002/bse.2259

Kirchherr, J., Reike, D., \& Hekkert, M. (2017). Conceptualizing the circular economy: An analysis of 114 definitions. Resources, Conservation and Recycling, 127, 221-232. https://doi.org/10.1016/j.resconrec.2017.09.005

Korhonen, J., Nuur, C., Feldmann, A., Birkie, S.E., (2018). Circular economy as an essentially contested concept. Journal of Cleaner Production, 175, 544-552. https://doi.org/10.1016/j.jclepro.2017.12.111

Kristensen, H.S., \& Mosgaard, M.A. (2020) A review of micro level indicators for a circular economy - moving away from the three dimensions of sustainability? Journal of Cleaner Production, 243, 118531. https://doi.org/10.1016/j.jclepro.2019.118531

Lahane, S., Kant, R., \& Shankar, R. (2020). Circular supply chain management: A state-of-art review and future opportunities. Journal of Cleaner Production, 120, 85-9. https://doi.org/10.1016/j.jclepro.2020.120859

Lieder, M., \& Rashid, A. (2016). Towards circular economy implementation: a comprehensive review in context of manufacturing industry. Journal of Cleaner Production, 115, 36-51. https://doi.org/10.1016/j.jclepro.2015.12.042

Lim, W.M. (2017). Inside the sustainable consumption theoretical toolbox: Critical concepts for sustainability, consumption, and marketing. Journal of Business Research, 78, 69-80. https://doi.org/10.1016/j.jbusres.2017.05.001

Liu, L., Liang, Y., Song, Q., Li, J., (2017). A review of waste prevention through 3R under the concept of circular economy in China. Journal of Material Cycles and Waste Management, 19 (4), 1314-1323. https://doi.org/10.1007/s10163-017-0606-4

Liu, Z., Adams, M., Cote, R. P., Geng, Y., \& Li, Y. (2018). Comparative study on the pathways of industrial parks towards sustainable development between China and Canada. Resources, Conservation and Recycling, 128, 417-425.

https://doi.org/10.1016/i.resconrec.2016.06.012

Lloret, A. (2016). Modeling corporate sustainability strategy. Journal of Business Research, 69(2), 418-425.

https://doi.org/10.1016/j.jbusres.2015.06.047

Malinauskaite, J., Jouhara, H., Czajczyńska, D., Stanchev, P., Katsou, E., Rostkowsk, P., Anguilano, L., (2017). Municipal Waste

Management and Waste-to-energy in the Context of a Circular Economy and Energy Recycling in Europe. Energy, 141,2013 - 2044. http://dx.doi.org/10.1016/j.energy.2017.11.128

Marino, A., Paolo P. (2020). Comparing European countries' performances in the transition towards the Circular Economy. Science of the Total Environment 729, 138142 https://doi.org/10.1016/j.scitotenv.2020.138142

Mazzoni, F. (2020). Circular economy and eco-innovation in Italian industrial clusters. Best practices from Prato textile cluster. Insights into Regional Development, 2(3), 661-676. https://doi.org/10.9770/IRD.2020.2.3(4)

Meadows D., H., Meadows D., L., Randers J., Behrens III W., W. (1972). The Limits to growth; a report for the Club of Rome's project on the predicament of mankind. New York Universe Books.

Michelini, G., Moraes, R.N., Cunha, R.N., Costa, J.M.H., Ometto, A.R., (2017). From linear to circular economy: PSS, conducting the transition. Procedia CIRP, 64 (2017), 2-6. https://doi.org/10.1016/j.procir.2017.03.012

Minelgaite, A., Liobikiene, G., (2019). Waste problem in European Union and its influence on waste management behaviours. Science of the Total Environment 667, 86-93. https://doi.org/10.1016/j.scitotenv.2019.02.313

Milios, L., Beqiri, B., Whalen, K. A., \& Jelonek, S. H. (2019). Sailing towards a circular economy: Conditions for increased reuse and remanufacturing in the Scandinavian maritime sector. Journal of Cleaner Production, 225, 227-235.

https://doi.org/10.1016/j.jclepro.2019.03.330

Møller, H., Hanssen, O.J., Svanes, E., Hartikainen, H., Silvennoinen, K., Gustavsson, J., Östergren, K., Schneider, F., Soethoudt, H., Canali, M., Politano, A., Gaiani, S., Redlingshöfer, B., Moates, G., Waldron, K., Stenmarck, A., (2014). Standard approach on quantitative techniques to be used to estimate food waste levels. Ostfold Research Report. Retrieved on march 5, 2020 from https://www.eu-

fusions.org/index.php/

Murray, A., Skene, K., Haynes, K., (2017). The circular economy: an interdisciplinary exploration of the concept and application in a global context. Journal of business ethics 140 (3), 369-380. https://doi.org/10.1007/s10551-015-2693-2

Neuman, W. L. (2014). Basics of social research. Pearson/Allyn and Bacon

OECD, (2016). Extended producer responsibility. Updated guidance for efficient waste management.

http://www.oecd.org/development/extended-producer-responsibil- ity-9789264256385-en.htm.

OECD, (2017). Making the Slovak Republic a more resource efficient economy. Retrieved on December 5, 2020 from

http://www.oecd.org/environment/waste/Policy-Paper-Making-the-Slovak-Republic-a-more-resourceeicient-economy.pdf. 


\section{ENTREPRENEURSHIP AND SUSTAINABILITY ISSUES}

ISSN 2345-0282 (online) http://jssidoi.org/jesi/

2021 Volume 8 Number 4 (June)

http://doi.org/10.9770/jesi.2021.8.4(26)

Parida, V., Burstrom, T., Visnjic, I., \& Wincent, J. (2019). Orchestrating industrial ecosystem in circular economy: A two-stage transformation model for large manufacturing companies. Journal of Business Research, 101, 715-725.

https://doi.org/10.1016/i.jbusres.2019.01.006

Pieroni, M. P., McAloone, T. C., \& Pigosso, D. C. (2019). Business model innovation for circular economy and sustainability: A review of approaches. Journal of cleaner production, 215, 198-216. https://doi.org/10.1016/j.jclepro.2019.01.036

Preston, F., (2012). A global redesign? Shaping the circular economy. Energy, Environment and Resource Governance 02,1 - 20

Retrieved on April 5, 2020 from http://ec.europa.eu/environment/eir/country-reports/index2_en.htm.

Rizos, V., Behrens, A., Kafyeke, T., Hirschnitz-Garbers, M., Ioannou, A., 2015. The Circular Economy: Barriers and Opportunities for SMEs, CEPS Working Group - Work n. 412. Stahel, W.R., 2016. The circular economy. Nature 531, 435-438, 23.

https://doi.org/10.1038/531435a

Rosa, P., Sassanelli, C., \& Terzi, S. (2019). Circular business models versus circular benefits: An assessment in the waste from electrical and electronic equipments sector. Journal of Cleaner Production, 231, 940-952. https://doi.org/10.1016/j.jclepro.2019.117696

Saavedra, Y. M., Iritani, D. R., Pavan, A. L., \& Ometto, A. R. (2018). Theoretical contribution of industrial ecology to circular economy. Journal of Cleaner Production, 170, 1514-1522. https://doi.org/10.1016/j.jclepro.2017.09.260

Tvaronavičienè, M., Prakapienè, D., Garškaitė-Milvydienė, K., Prakapas, R., \& Nawrot, Ł. (2018). Energy efficiency in the long run in the selected European countries. Economics and Sociology, 245-254. http://doi.org/ 10.14254/2071- 789X.2018/11-1/16

Türkeli, S., Kemp, R., Huang, B., Bleischwitz, R., \& McDowall, W. (2018). Circular economy scientific knowledge in the European Union and China: A bibliometric, network and survey analysis (2006-2016). Journal of Cleaner Production, 197, 1244-1261.

https://doi.org/10.1016/j.jclepro.2018.06.118

UN Environment, (2019). Global resources outlook natural resources for the future we want. Retrieved on April 5, 2020 from

http://www.resourcepanel.org/reports/global-resources-outlook.

Winkler, H. (2011). Closed-loop production systems-A sustainable supply chain approach. CIRP Journal of Manufacturing Science and Technology, 4(3), 243-246. https://doi.org/10.1016/j.cirpj.2011.05.001

World Bank Group, 'Doing Business (2019). World Bank Doing Business report Retrived on January 12, 2021 from

https://www.doingbusiness.org/en/reports/global-reports/doing-business-2019

\section{Acknowledgements}

We declare that, the work has not been published previously, that it is not under consideration for publication elsewhere, that its publication is approved by all authors and tacitly or explicitly by the responsible authorities where the work was carried out, and that, if accepted, it will not be published elsewhere in the same form, in English or in any other language, including electronically without the written consent of the copyright-holder.

Alfonso MARINO, professor circular economy, (Università della Campania - Luigi Vanvitelli) degree in business economics with specific competencies in sustainability and circular economy.

ORCID ID: https://orcid.org/0000-0003-1722-0539

Paolo PARISO, PhD student in business economics, (Università della Campania - Luigi Vanvitelli) degree in business economics, with specific competences in SMEs.

ORCID ID: https://orcid.org/0000-0003-1066-4102

Make your research more visible, join the Twitter account of ENTREPRENEURSHIP AND SUSTAINABILITY ISSUES: @Entrepr69728810

Copyright (C) 2021 by author(s) and VsI Entrepreneurship and Sustainability Center

This work is licensed under the Creative Commons Attribution International License (CC BY). http://creativecommons.org/licenses/by/4.0/

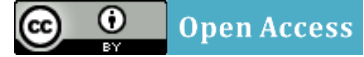

